\title{
Health tourism courses in Iran and the country's potential in becoming the health tourism education hub in the Middle East region
}

\author{
Mohammadreza Maleki ${ }^{1}$, Niusha Shahidi Sadeghi*1 ${ }^{\mathbb{D}}$, Saeed Hashemzadeh${ }^{2}$, Jalil Koohpayehzadeh ${ }^{3}$, Alireza Askari $^{4}$ \\ Received: 12 Nov 2019 \\ Published: 2 Sep 2020
}

Conflicts of Interest: None declared

Funding: None

*This work has been published under CC BY-NC-SA 1.0 license.

Copyright $\odot$ Iran University of Medical Sciences

Cite this article as: Maleki M, Shahidi Sadeghi N, Hashemzadeh S, Koohpayehzadeh J, Askari A. Health tourism courses in Iran and the country's potential in becoming the health tourism education hub in the Middle East region. Med J Islam Repub Iran. 2020 (2 Sep);34:112. https://doi.org/10.47176/mjiri.34.112

\section{Dear Editor,}

During recent years, economic attractiveness, The pristine health tourism (HT) market in Iran, Iran's medical reputation among neighboring countries, and Policymakers' determination to develop it were the motivating factors for the entrance of many individuals and institutions to this industry $(1,2)$. Thus, the HT market in addition to the numerous challenges such as the appearance of amalgam actors and lack of a defined mechanism, suddenly faced with the more important challenge of the widespread presence of less acquainted individuals in this field. On the other hand, Iran's small share of the number of health tourists and its concentration in a few cities indicate that this field is underdeveloped (3).

In this regard, lack of trained personnel can be mentioned as one of the important obstacles of medical tourism development in Iran and worldwide (2, 4, 5). Studies also show that the development of HT education as a distinct part of the health scope increases the efficiency and effectiveness of programs, decreases medical errors, and increases satisfaction (6-9). In developed countries, priority strategy for policymakers in order to promote this market and avoiding its negative effects is to ensure training for employees $(6,10,11)$ in less developed countries, due to the role of governments in developing medical tourism facilities, researches have emphasized the special focus of the public education system as well as private education systems (6). Recently also, international standards such as pass the training courses for physicians as one of the evaluation indicators have been proposed for the development of medical tourism $(7,12)$.

As stated before, during the past few years, Iran had no defined mechanisms for admission and treatment of international patients. Therefore, according to HT stakeholders in Iran, who were chief physician and nurses of the International Patient department, the physicians in charge of the facilitation tourism companies, and the managing directors of travel services offices, HT Skills-Based Courses were designed and implemented in 2016 in a 6 month period. These were national courses in collaboration with the Office of Supervision and Accreditation of Hospitals Affairs of the Ministry of Health and School of Health Management and Information Sciences of Iran University of Medical Sciences. Studies also show that training programs should be designed and implemented by policymakers for the effective performance of all stakeholders, not just clinical staff, through needs assessment of stakeholders and authorities as well as the use of legal programs $(6,13)$. thus, Curriculum of the basic course was exactly designed in accordance to today's requirements and Hospitals` International Patient department regulation and acquiring views of all involved organizations such as Cultural Heritage Organization, Ministry of Foreign Affairs, and etc. For the quality and security maintenance of the courses, a variety of measures such as electronification of the sign-up process to certification, on-site take photos from the learner, security holograms, the presence of ministerial experts and non-government funding have been embedded.

The first Advanced Course was held with the focus on "Marketing and Branding in HT" with a Skill-based Workshop in May 2019. In fact, advanced courses were designed and developed in response to the demand of HT activists and urgency to respond to this requirement over a

Corresponding author: Niusha Shahidi Sadeghi, shahidi.n@iums.ac.ir

1. Department of Health Services Management, School of Health Management and Information Sciences, Iran University of Medical Sciences, Tehran, Iran

2. Deputy of Treatment, Ministry of Health, Tehran, Iran

3. Department of Community Medicine, School of Medicine, Iran University of Medical Sciences, Tehran, Iran

4. Department of Orthopedics, School of Medicine, Iran University of Medical Sciences, Tehran, Iran 
five-month period in 2018. The second axis of these courses was held on the subject of "systematic thinking" in October 2019.

As a result of 20 basic courses, 515 participants were trained for 24 hours. Also, 96 participants trained in 4 advanced courses. There are Significant statistics available about the number of participants from a single institution and as well as the presence of managers and deans of institutions in basic and advanced courses. Also, the wide range of participants in terms of demographic characteristics indicates that the presence of diverse and enthusiastic activists in the HT sector.

Most of the trainings in HT are not academic. Also these trainings will be held periodically and participants will receive a certificate, just like what is happening in Iran (12). But researchers believe that in order to provide evidence-based and high-quality services, professionals of this field must have a certain level of academic education (14). Over the last few decades, a debate has been arisen about necessity and urgency for obtaining a university degree in addition to short-term tourism courses and HT field in particular (15-18). Also, surveys indicate that there are short-term, long-term, and higher education courses just in medical tourism in some countries such as Germany, Austria, England, Hungary, Ireland, and India (19-26). Therefore, the absence of education vacancies comprehensively is tangible for all HT fields and not just in medical tourism, especially in the Middle East. So, regarding the lack of similar courses in the region, the development of the short-term courses and also establishment of an academic course is a golden opportunity to raise funds and build the capacity of becoming the educational hub in the Middle East and West Asia; it should be considered by policymakers.

\section{Conflict of Interests}

The authors declare that they have no competing interests. the effects of medical tourism in destination and departure countries? A scoping review. Int J Equity Health. 2010;9:24.

10. Crooks VA, Li N, Snyder J, et al. "You don't want to lose that trust that you've built with this patient...": (dis)trust, medical tourism, and the Canadian family physician-patient relationship. BMC Fam Pract. 2015;16:25.

11. Ganguli S, Ebrahim AH. A qualitative analysis of Singapore's medical tourism competitiveness. Tourism Manag Perspect. 2017;21:7484 .

12. Fetscherin M, Stephano R-M. The medical tourism index: Scale development and validation. Tour Manag. 2016;52:539-556.

13. Schobersberger W, Hoffmann G, Humpeler E. The Growing Role of Health in Tourism. In: Kronenberg C, Müller S, Peters M, Pikkemaat B, Weiermair K, editors. Change Management in Tourism from 'Old' to 'New' Tourism. Berlin: Erich Schmidt Verlag; 2008.p. 113-129.

14. Strauss-Blasche G, Reithofer B, Schobersberger W, Ekmekcioglu C, Marktl W. Effect of vacation on Health: Moderating factors of vacation outcome. J Travel Med. 2005;12:94-101.

15. Heydari Chianeh R, Nasrollahzadeh Z, Abdollahi M. An Evaluation of Tourism Higher Education in Iran Based on SWOT Model. Tourism Plan Develop. 2012;1(1):129-152.

16. Blank C, Riedler C, Schobersberger W. Academic Education in Health Tourism-Knowledge about and Willingness for Academic Training within the Field of Health Tourism: A Cross-Country Evaluation within the German- Speaking Alpine Area. J Tourism Hosp. 2013;2:109.

17. Berg W. Gesundheitstourismus und Wellnesstourismus. Oldenbourg Verlag Wissenschaftsverlag GmbH, München; 2008.

18. McKercher B. The future of tourism education: An Australian scenario?. Tourism and Hospitality Research. 2002; 3(3):199-210.

19. http://www.bbw-hochschule.de/masters-program-in-business.html

20. https://fh-joanneum.at/gesundheitsmanagement-im-tourismus/ master/en/my-studies/degree-programme/

21. https://www.th-deg.de/en/agw/courses/itm-b-en/subjectoverview? highlight=WyJtZWRpY2FsliwidG91 cmlzbSIsIm11ZGljYWwgdG91 cmlzbSJd

22. http://www.thecompleteuniversityguide.co.uk/courses/610395

23. http://uni.sze.hu/en GB/bsc-ba-courses

24. http://www.jliedu.com/programs/detail/professional-diploma-inmedical-tourism-healthcare-marketing

25. http://www.ait.ie/aboutaitandathlone/courses/bahonsinwellnesstouris mmanagement/

26. https://www.th-deg.de/en/agw/courses/itm-m-en

\section{References}

1. Firozjaeian A, Firozjaeian M, Patrodi HH, Rezazadeh FG. Application techniques interpretive structural modeling (ISM) in tourism studies (pathological analytical approach). Tourism Plan Develop. 2013;2(6):129-59.

2. Izadi M, Saadat SH, Ayoubian A, Hashemi Dehaghi Z, Karbasi MR, Jalali AR. Health tourism in Iran; identifying obstacles for Development of This Industry. Int J Travel Med Glob Health. 2013;1(3):8994.

3. http://iht.en.behdasht.gov.ir/index.aspx?siteid $=430$

4. Khan MJ, Chelliah S, Haron MS, Ahmed S. Role of travel motivations, perceived risks and travel constraints on destination image and visit intention in medical tourism: theoretical model. Sultan Qaboos Univ Med J. 2017;17(1):e11-e17.

5. Fisher C, Sood K. What is driving the growth in medical tourism? Health Mark Q. 2014;31(3):246-262.

6. Savasan A, Uzunboylu H, Tuncel E. Training in medical tourism, a necessity or a perspective? a needs analysis of stakeholders on training issues in medical tourism. Int J Educ Sci. 2016;15(1-2):225-33.

7. Kacha O, Kovacs BE, McCarthy C, et al. An approach to establishing international quality standards for medical travel. Front Public Health. 2016;4:29.

8. Ayoubian A, Tourani S, Hashemi Dehaghi Z. Medical Tourism Attraction of Tehran Hospitals. Int $\mathrm{J}$ Travel Med Glob Health. 2013;1(3):95-98.

9. Johnston R, Crooks VA, Snyder J, Kingsbury P. What is known about 